some Moinian in the east, the Armadale-Strathy area.

Garson and Plant ${ }^{1}$ and Johnson ${ }^{2}$ mention ultrabasic bodies intruding the Moinian and the Lewisian of Sutherland, as originally described by $\operatorname{Read}^{8}$. Our detailed field mapping has shown them to be restricted to the Lewisian. $\operatorname{Read}^{8}$ and the later authors ${ }^{1,2}$ apparently confuse a series of Lewisian metaperidotites and garnet pyroxene rocks (garnet pyriclasites) with early Moinian metabasic intrusives. Geochemical and petrological evidence indicates that the garnet pyroxene rocks of the Naver and Borgie $^{6}$ Lewisian are identical to those of the foreland Lewisian $^{9,10}$. Similarly, the metaperidotites are identical to analogous rocks found throughout the foreland Lewisian ${ }^{8,10,11}$. These bodies are not, therefore, synchronous with the emplacement of the Lewisian sheets (see ref. 2), they are an integral part of them. Neither are they high level diapirs (see ref. 2); nor do they constitute a Moinian ophiolite zone (see ref. 1).

Several authors have speculated an extension of the Sgurr Beag Slide S2 $^{12}$ into central Sutherland ${ }^{2,13,14}$. Although slides are present there is no definite evidence that any are continuous with the Sgurr Beag Slide. The Lewisian sheets of central Sutherland seem to have been emplaced by a combination of early (F1) isoclinal folding and possible sliding, which has been modified by later (F2) folding and sliding. The continuation of the Sgurr Beag Slide may, however, occur in northeastern Sutherland, thus extending Johnson's speculation ${ }^{2}$, the Lewisian of central and northern Sutherland may be the root zone of Morarian nappes represented by the large areas of Lewisian in north-eastern Sutherland.

Steven J. MoOrhouse VALERIE E. HARRISON

Department of Geology,

University of Hull,

Hull HU6 $7 R X, U K$

1 Garson, M., and Plant, J., Nature phys. Sci., 242 34-37 (1973).

2 Johnson, M. R. W., Nature, 257, 301 (1975).

3 Brown, P. E., Contr. Miner. Petrol, 14, 1-26 (1967)

Tarney, J., Skinner, A. C., and Sheraton, J. W Proc. $X X X I V$ int geol. Congr. (Montreal), 1,162 174 (1900).

Sheraton, J. W., Skinner, A. C.. and Tarney, J. The Early Precambrian of Srotland and Related Rocks of Greenland, 13-30 (University of Keele. 1973)

6 Moorhouse, S. J., Scott. J. Geol. (in the press).

Leake, R. C., and Aucott, J. W. Fourth int. geochem.expl. Symp., 389-400(1973).

Read, H. H. Mem. geol. Surv, U.K. (1931).

9 O'Hara, M. J., Geol. Mag., 103, 284 (1966). Bowes, D. R., Wright, A. E., and Park, R.
Q. Jl geol. Sor. Lond., $120,153-192$ (1964).

1 Peach, B. N., et al., Mem. geol. Sinty. G.B. (1907). 433-463 (1971).

3 Sutton, J., Proc. geol. Soc. Lond., 1664, 263 (1971). (1974).

\section{Evolutionary changes in insulin}

BLundell and Wood" propose "a model for the evolution of insulin mainly in terms of adaptive processes". Simultaneously they raise questions regarding "conclusions made on the basis of uniform rates and changes that seem not to affect function", such conclusions being attributed to Kimura ${ }^{2}$ and to King and Jukes ${ }^{3}$. They do not mention the more recent discussion by Kimura and $\mathrm{Ohta}^{4}$, who point out that insulin in general has a very low evolutionary rate, corresponding to a strong negative-selection barrier. Blundell and Wood's model calls for functional restraints on most of the amino acid residues. Kimura and Ohta also noted that the $\mathrm{C}$ peptide of proinsulin evolves about 10 times as fast as insulin, and is therefore a much better candidate for neutral mutations than insulin itself. and they proposed that the absence of zinc from guinea pig insulin results in a loss of constraint on the fixation of mutations.

\section{Space Sciences Laboratory,}

University of California.

Berkeley, California 94720

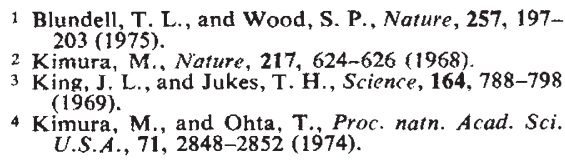

\section{Specificity of transfer factor}

IN an article on the use of transfer factor (TF) in treatment of viral infections', Zuckerman states that "clinically, TF activates uncommitted and non-sensitised lymphocytes of the recipient so that new clones of antigenspecific cells are produced". He goes on to make the point that the delayed-type skin reactivities that are transferred after injection of TF are those possessed by the donor. It is undoubtedly true that the results obtained during the past 25 yr by Lawrence and others are most readily explained by the existence of such specificity ${ }^{2}$. The problem is, however, that nobody has found a way in which specificity can be demonstrated in unequivocal terms and by procedures which allow for confirmation in other laboratories. At the recent Second International Workshop on Basic Properties and Clinical Applications of Transfer Factor at Fort Detrick, there were more than 100 participants and not one convincing demonstration of specificity.

Failure to convince does not disprove the concept of antigen specificity. but it is worrying. It may be due to the difficulties of human experimentation and the lack of a satisfactory animal model. One possibility is that TF preparations contain both a specific factor and nonspecific adjuvant-like factors, and that this is creating problems in man where the antigens normally studied are not complete strangers to the 'negative' donors and recipients. The various in vitro systems that have been used have not pointed to specificity, although there is no guarantee that the factors active in vivo are being assayed. The work of one of us has involved the action of human TF on macrophage migration and lymphocyte transformation $^{3,4}$. Evidence obtained in the latter system suggests that the action of TF is nonspecific but that the level of this nonspecific activity is greater in tuberculin-positive than in negative individuals.

Doubts about specificity are especially relevant in the clinical field where there is clear evidence that TF can boost phytohaemagglutinin responsiveness and the number of cells forming rosettes with sheep erythrocytes ${ }^{5,6}$. This nonspecific action could be responsible for the appearance of delayed hypersensitivity and clinical improvement.

\section{R. Salaman H. VALDIMARSSON}

Department of Immunology, St Mary's Hospital Medical School, London W2 IPG, UK

\section{Zuckerman, A. J., Nature, 258, 14 (1975). \\ Lawrence, H. S., Adv. Immun, 11,195 (1969). Salaman, M. R., Immunology, 26, 1069 (1974). Salarnan, M. R., Proc. second Int. Workshop Basic
Properties and Clinical Applications of Transfer Properties and Clinical Applications of Transfer Factor (Academic. New York, in the press).
Wybran, J., Levin, A. S., Spitler, L. E., and Fuden- berg, H. H., N. Engl.J. Med., 288, 710 (1973). Valdimarsson, H., Hambleton, G., Henry, K., and McConnell, I., Clin. exp. Immun., 16, 141 (1974).}

\section{Insectivorous grouse?}

BEFORE embarking on the "full-scale investigation of the relationship between grouse and insects" recommended by your Animal Ecology Correspondent', the cautious research worker might wish to establish that incubating hen red grouse do in fact eat many tipulids. This is crucial to the suggestion that hen grouse on wet moors may rely on tipulids to redress their supposed state of 'nutrient depletion' after egg laying. The work by Butterfield and Coulson ${ }^{2}$ did not show that adult hen grouse eat tipulids at this stage, although it would not be surprising if readers of their paper were to infer that they do.

Although Butterfield and Coulson present data for the month of May, when hens are incubating, the droppings that they collected in May were from cock grouse. How do we know this? When incubating, hen grouse 